\title{
DISTRIBUTION AND SEASONAL VARIATION OF HEAVY METALS IN SEDIMENTS OF MUTHUPET LAGOON, SOUTHEAST COAST OF INDIA
}

\author{
Thirunavukkarasu Balakrishnan', Arumugam Sundaramanickam', Sudhanshu Shekhar', \\ Thangavel Balasubramanian ${ }^{1}$
}

1 CAS in Marine Biology, Faculty of Marine Sciences, Annamalai University, Parangipettai 608 502, India, e-mail: eggsandlarvae@gmail.com

Received: 2015.02 .18

Accepted: 2015.06.02

Published: 2015.07.01

\begin{abstract}
This study deals with seasonal variation of heavy metals in sediments of Muthupet lagoon, Southeast coast of India from September 2011 to August 2012. The bulk sediments were association with sand, silt and clay. Geo-accumulation index (lgeo) was used to quantitatively assess the influences of heavy metal pollution. Heavy metals were determined by using Inductively Coupled Plasma Optical Emission Spectrometer (ICP-OES) and the results were compared to permissible limits of WHO/USEPA. The minimum concentration of heavy metals in all the stations were found during the post monsoon and summer seasons and the maximum concentration of heavy metals in all the stations were found during the pre-monsoon and monsoon seasons. The reason for the pollution was land drainage, irrigation through channels and municipal wastes and also the peak agricultural activities due to the release of fresh water from reservoirs. Among all the metals iron was found to be maximum in all the stations in post-monsoon and summer season followed by magnesium and manganese. Apart from these three metal, all other six metals are recorded in moderate range. The reason for the high concentration of these metals are anthropogenic activity, agriculture, aquaculture and the rivers regular in and out flow throughout the study duration in the lagoon area.
\end{abstract}

Keywords: seasonal variation, heavy metals, Muthupet lagoon.

\section{INTRODUCTION}

Sediments are important carriers of heavy metals in the hydrological cycle and because metals are partitioned with the surrounding waters, they reflect the quality of an aquatic system. Heavy metals are one of the most serious pollutants in marine environment; it is mainly due to their persistence and accumulation in organisms [Chinnaraja et al., 2011].

A development of industrialization and human activity has an impact on several biological processes [Greaney, 2005]. Besides their natural occurrence, heavy metals may enter the ecological system through anthropogenic activities such as, sewage sludge disposal, application of pesticides and organic fertilizers as well as atmospheric deposition [Haiyan and Stuanes, 2003]. In marine sediments, the concentration of heavy metals measured is $0.01 \mu \mathrm{g} / \mathrm{g}^{-1}$ dry weight, whereas in contaminated sediments the concentration may reach to 10 or $100 \mu \mathrm{g} / \mathrm{g}$ [Everaarts et al., 1989; Zainal 2000]. In fact, metals can enter the sea dissolved or aggregated to particles that settle in the estuary mouth. The biological and chemical conditions of estuaries have an important influence on the distribution of metals and metalloids, but the transport pathways and distribution in all the stages of the estuary are not still recognized [Huntley et al., 2001]. The trace metals carried by water can undergo complexion, ion exchange or precipitation reactions as well as biological processes. Due to all these processes, the concentration of trace elements can vary according to spatial (depth, closeness to the mouth or to the shore, level of stratification, etc.) and temporal (seasonal or tidal effects) variations. In view of that, the present study was designed to under- 
stand the seasonal and spatial distribution pattern of heavy metals $(\mathrm{Cd}, \mathrm{Cr}, \mathrm{Cu}, \mathrm{Fe}, \mathrm{Mn}, \mathrm{Ni}, \mathrm{Pb}$ and $\mathrm{Zn}$ ) in sediments and its binding ability in relation to sediments texture from lagoon ecosystem and also to evaluate the metals pollution level comparing with international standards.

\section{STUDY AREA}

Muthupet Lagoon wetland Station 1. $10^{\circ} 19.42$ $\mathrm{N}$ and Longitude $79^{\circ} 32.65 \mathrm{E}$, Station 2 Latitude $10^{\circ} 18.26$ and Longitude $79^{\circ} 32.14$, Station 3, Latitude $10^{\circ} 18.53$ and Longitude $79^{\circ} 31.33$, Station 4 Latitude $10^{\circ} 19.24$ and Longitude $79^{\circ} 33.45$, Station 5, Latitude $10^{\circ} 20.35$ and Longitude $79^{\circ} 33.45$ and Station 6 Latitude $10^{\circ} 20.41$ and Longitude $79^{\circ} 32.32$ of Vedaranyam area is located in the southern most end of the Cauvery delta in the districts of Nagapattinam, Thrivarur and Thanjavur. It is a part of a large coastal wetland complex called the Great Vedaranyam Swamp. This area has a gentle slope towards Palk Strait of Bay of Bengal. The distributaries of Cauvery viz., Paminiyar, Koraiyar, Kandaparichanar, Kilaithangiyar and Marakkakoraiyar discharge their water into the wetlands and form a large lagoon before reaching the Bay of Bengal (Figure 1). Besides the lagoon, the wetland supports many tidal creeks, channels and small bays, which are bordered by thick mangroves; and a number of manmade canals dug across the mangroves, particularly in their western part. The lagoon receives freshwater inflow during northeast monsoon (October - December) Copies amount of freshwater discharge was reported from February to September. The soil in the lagoon is clayey silt and towards the landward side it is silt clay due to the continues fresh silt deposition.

\section{MATERIALS AND METHOD}

\section{Sampling}

Sediment samples were collected seasonally from all the six station selected transects in the Muthupet Lagoon for the period of one year (September 2011 to August 2012) four seasons i.e. summer (April - June), Pre-monsoon (July September), monsoon (October - December) and Post monsoon (January - March) using Peterson grab which has an area of $0.2 \mathrm{~m}^{2}$. The collected sediments were preserved in pre-cleaned polythene bags and brought to the laboratory for further analysis.

\section{Sample processing}

Ingram (1970) procedure was used to study the soil texture. For the heavy metals, the sediment samples were dried at $150{ }^{\circ} \mathrm{C}$ for 5-6 hrs. The dried samples were ground to powder in a glass mortar and stored in pre-cleaned polythene bags. $250 \mathrm{mg}$ of sediment samples was taken and

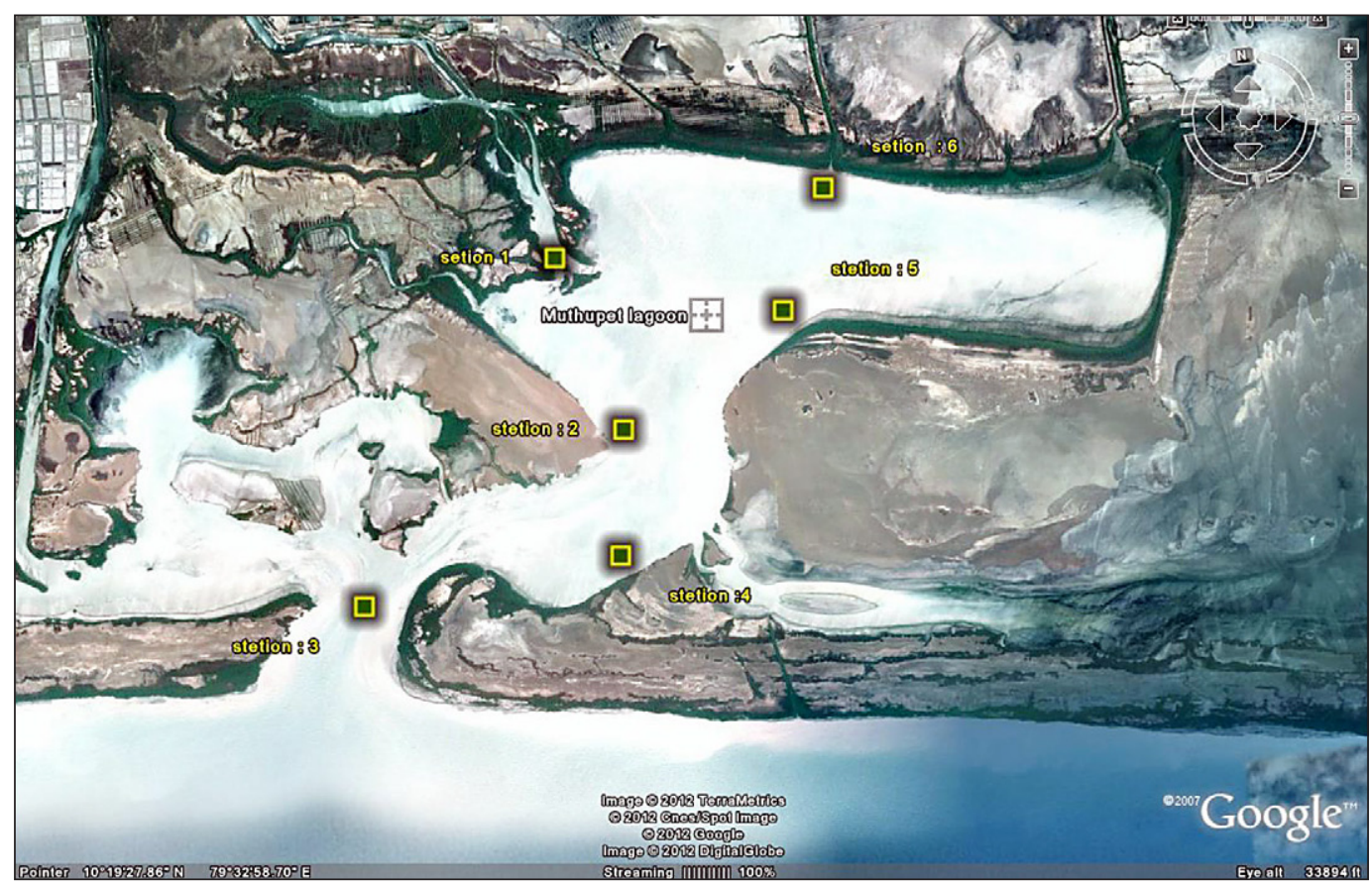

Figure 1. Study area Muthupettai lagoon, Southeast coast of India 
digested with a mixture of $1 \mathrm{ml}$ conc. $\mathrm{H}_{2} \mathrm{SO}_{4}, 5$ $\mathrm{ml}$ conc. $\mathrm{HNO}_{3}$ and $2 \mathrm{ml}$ of conc. $\mathrm{HClO}_{4}$. A few drops of HF (Hydrofluoric acid) were added in order to achieve complete dissolution of the materials. The mixture was boiled, evaporated to near dryness and then suspended in $10 \mathrm{ml} 2 \mathrm{~N} \mathrm{HCl}$. This sample was passed through a filter paper and made up to $25 \mathrm{ml}$ with metal free double distilled water. The resulting solution was then stored in polypropylene containers. The final concentrations of metal $\mathrm{Cu}, \mathrm{Zn}, \mathrm{Fe}, \mathrm{Cr}, \mathrm{Mg}, \mathrm{Mn}, \mathrm{Ni}, \mathrm{Pb}$ and $\mathrm{Cd}$ in the sediment were determined by aspirating the solution to a standard Flame Atomic Absorption Spectrophotometer [Sankar et al., 2010] and the metal contents in the sediments were expressed as $\mu \mathrm{g} / \mathrm{g}$.

\section{Statistical analysis}

Multivariate statistical analyses including Pearson correlation analysis were conducted using the statistical software SPSS for Windows Ver. 16 to identify the association of metals and geochemical parameters [Chork and Govett, 1985; Aitchison, 1986].

\section{Geo-accumulation index (Igeo)}

An approach to estimating the enrichment of metals concentration above background or baseline concentration is to calculate the geo-accumulation index (lgeo), as proposed by Muller (1969). This is a quantitative measure of the metal pollution in aquatic sediments [Ranjan et al., 2008].
It is calculated as follows:

$$
\mathrm{I}_{\text {geo }}=\operatorname{Iog}_{2}\left(\mathrm{C}_{\mathrm{n}} / 1.5 \mathrm{~B}_{\mathrm{n}}\right)
$$

where: $C_{n}-$ the concentration of the of the element in the samples,

$\mathrm{B}_{\mathrm{n}}$ - the geochemical background values or pristine values of the elements,

1.5 - the introduced to minimize the effect of possible variation in the background values.

\section{RESULTS AND DISCUSSION}

\section{Sediments texture}

Seasonal variations of sediments texture (\%) in Muthuppetai lagoon are shown in Figure 2. Textural data of the collected sediment sample are presented as mud $(7-15 \%$ sand, $22-27 \%$ silt and $60-69 \%$ clay) which reveals that there has been an insignificant variation found between seasonal and spatial variation except slit has been found significant variation in seasons of sediments in the lagoon area. The spatial variation of sediments texture of sand, silt and clay was found insignificant variation at stations. It was indicates that the lagoon environment promotes early flocculation of sand and clay particle into the lagoon. Observations revealed that there has been a pulsating supply of fine sediments in the lagoon dominated by mangroves due to the high energy coastal environment and the river flow [Ergin and Yörük, 1990]. The sand concentration varied from mini-

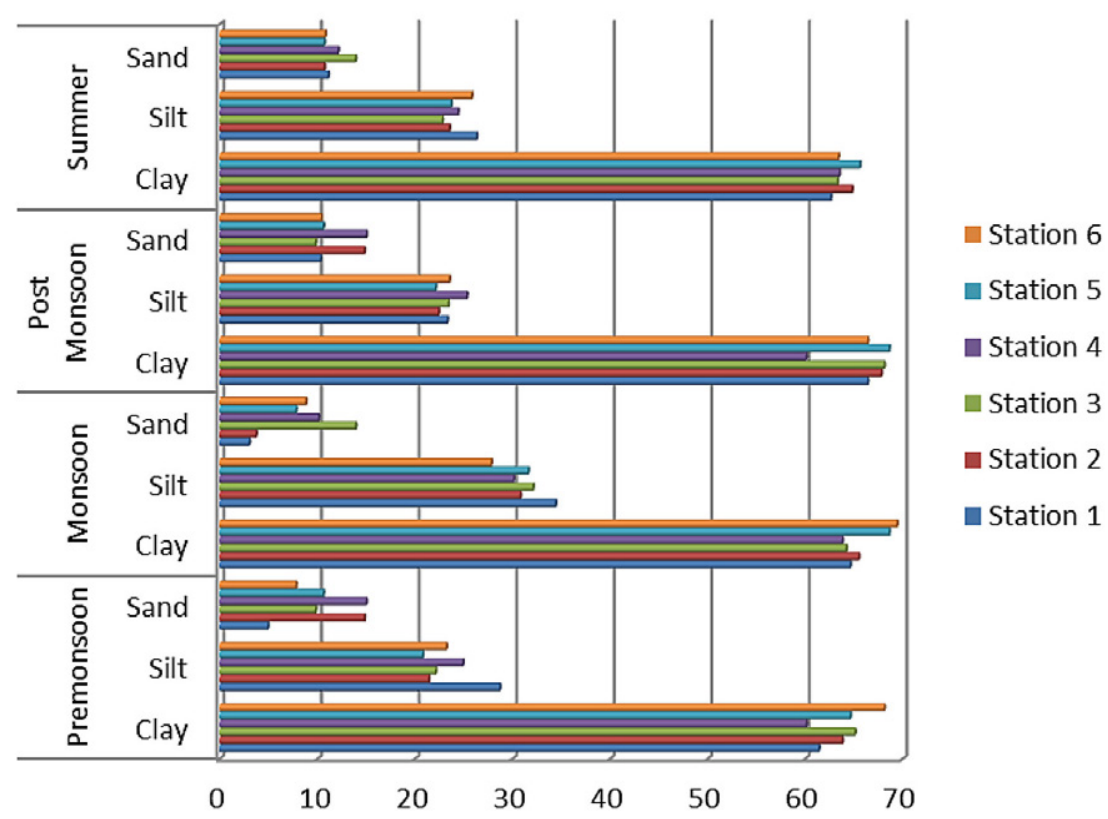

Figure 2. Seasonal veriation of sediment texure (\%) in Muthuppetai lagoon 
mum at $7.7 \%$ in pre monsoon season to maximum at $15 \%$ in post monsoon season. Silt concentration varied between $20.7 \%$ to $26.3 \%$ in monsoon and summer season and clay concentration was found to be dominant with a range of $60.1 \%$ in post monsoon season and $69.2 \%$ in pre monsoon season in all the stations throughout the study period. This can be confirmed by the domination of mud $(80 \%$ approx.) in the sediments of the present study. In a similar study, nearly $85 \%$ of mud in lagoon was collected in the mouth region, which is selectively trapped by mangrove roots [Furukawa et al., 1997]. The mud could be due to the decomposition of mangrove detritus, litter and decomposition of dead organisms. This structure traps floating detritus and reduces flow, eventually creating conditions where in suspended clay and silt particles settled [Soto-Jimenez and Páez-Osuna 2001].

\section{Seasonal variation}

The seasonal variation of heavy metal concentration in sediments sample were shown in Figure 3A-I. In the present study cadmium concentration varied insignificantly $(\mathrm{P}>0.05)$ from 0.021 to $0.202 \mu \mathrm{g} / \mathrm{g}$. The maximum value of 0.202 $\mu \mathrm{g} / \mathrm{g}$ was observed in station 6 during monsoon season and the minimum $0.021 \mu \mathrm{g} / \mathrm{g}$ in station 5 during summer season, whereas average range $(0.1865 \mu \mathrm{g} / \mathrm{g})$ was recorded from all other stations throughout the study period. The sources of Cd release to the surrounding environment come from industrial activities and burning fossil fuels. The enrichment of $\mathrm{Cd}$ and human exposures are primarily the result of fossil fuel combustion, phosphate fertilizers, natural sources, iron and steel production, cement production, nonferrous metals production and municipal solid waste incineration [Manju et al., 2014].

The chromium concentration was found to be insignificantly $(\mathrm{P}>0.05)$ varied from 0.159 to $3.398 \mu \mathrm{g} / \mathrm{g}$. The maximum value of $3.398 \mu \mathrm{g} / \mathrm{g}$ was observed in station 3 in the pre monsoon and the minimum value of $0.159 \mu \mathrm{g} / \mathrm{g}$ in station 1 in the post monsoon season, whereas the average range $(5.9971 \mu \mathrm{g} / \mathrm{g})$ of chromium was recorded from all other stations throughout the study period. The increase in concentration during monsoon and pre-monsoon could be attributed to the peak agricultural and industrial activities and sewage waste waters release to the fresh water inflow from the reservoirs, the high concentrations of heavy metals that enter the river and mix up with seawater [Thilagavathi et al., 2011].
The copper concentration was significantly $(\mathrm{p}<0.05)$ varied from 0.054 to $2.645 \mu \mathrm{g} / \mathrm{g}$. The maximum value of $2.645 \mu \mathrm{g} / \mathrm{g}$ was observed in station 5 during post-monsoon season and the minimum value of $0.054 \mu \mathrm{g} / \mathrm{g}$ in summer season from station 1 , whereas average range (5.417 $\mu \mathrm{g} / \mathrm{g}$ ) of copper was recorded from all other stations throughout the study period. Earlier reports suggest that naturally occurring elements, such as $\mathrm{Cu}, \mathrm{Fe}, \mathrm{Mn}, \mathrm{Mg}$ and $\mathrm{Zn}$, are essential micronutrients for plants, but can become toxic at concentrations higher than the amount required for normal growth [Nies et al., 1999]. The Iron concentration was found significantly $(\mathrm{p}<0.05)$ varied from 9.836 to $553.8 \mu \mathrm{g} / \mathrm{g}$. The maximum concentration of $553.8 \mu \mathrm{g} / \mathrm{g}$ was observed in station 1 during pre-monsoon season and the minimum value of $9.836 \mu \mathrm{g} / \mathrm{g}$ in station 2 during post monsoon season whereas average range $(1371.218 \mu \mathrm{g} / \mathrm{g})$ was recorded from all other station throughout the study period. Previous studies in other mangrove systems in Dares Salaam city showed that benthic biota, polychaetes, also had high levels of Iron [Mremi and Machiwa, 2003; Mtanga and Machiwa, 2007].

The magnesium concentration was found significantly $(\mathrm{p}<0.05)$ varied from 12.79 to 225.2 $\mu \mathrm{g} / \mathrm{g}$. The maximum value of $225.2 \mu \mathrm{g} / \mathrm{g}$ was observed in station 3 in summer season and the minimum value of $12.79 \mu \mathrm{g} / \mathrm{g}$ was observed in station 4 from post monsoon season, whereas average range $(404.5583 \mu \mathrm{g} / \mathrm{g})$ of magnesium was recorded from all other stations throughout the study period. Higher concentration of exchangeable magnessium may be due to the amount of exchangeable and solutions form of magnessium in sediment samples. It is also attributed to weathering of minerals and their deposition in sediments. (Marathe et al., 2011). The manganese concentration was found significantly $(\mathrm{p}<0.05)$ varied between 0.479 to $29.89 \mu \mathrm{g} / \mathrm{g}$. The maximum manganese value of $29.89 \mu \mathrm{g} / \mathrm{g}$ was observed at station 4 in pre monsoon season and the minimum value of $0.479 \mu \mathrm{g} / \mathrm{g}$ in station 2 during post monsoon season whereas average $(57.03633 \mu \mathrm{g} / \mathrm{g})$ was recorded from all other stations throughout the study period. The manganese mobility is intermediate to low, except in the acid reducing environment of organic swamps and bogs where $\mathrm{Mn}$ can move very readily. Earlier reports suggest that manganese value ranges from $0.2-5.38$ $\mathrm{mg} / \mathrm{l}$, and average is $1.736 \mathrm{mg} / \mathrm{l}$ in the study and the manganese concentrations of the surface sedi- 

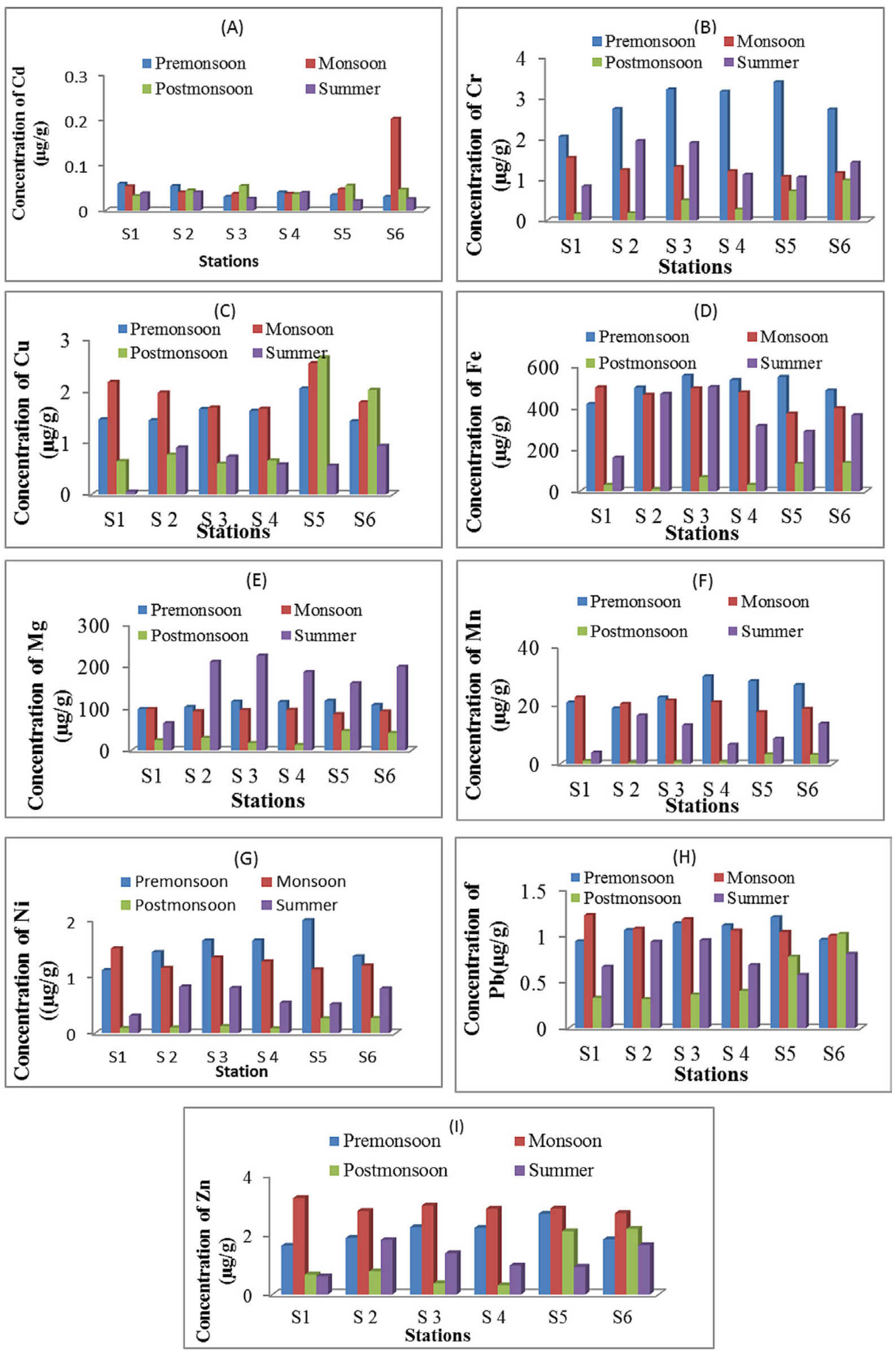

Figure 3A-I. Seasonal veriation of heavy metals consanretion in Muthuppetai lagoon 
ments from Bay of Bengal [Solai et al., 2013]. The low $\mathrm{Mn}$ concentration results due to lack of reducing conditions at depth in the sediment or possible under strong reducing conditions all reactive $\mathrm{Mn}$ has escaped to deeper water [Nolting and Everaarts, 1999].

The nickel concentration was found significantly $(\mathrm{p}<0.05)$ varied from 0.092 to $1.994 \mu \mathrm{g} / \mathrm{g}$. The maximum value of $1.994 \mu \mathrm{g} / \mathrm{g}$ was obtained in station 3 during pre-monsoon season and the minimum value of $0.092 \mu \mathrm{g} / \mathrm{g}$ was observed in station 1 in the post monsoon season whereas average range $(3.568 \mu \mathrm{g} / \mathrm{g})$ of nickel was recorded from all other stations throughout the study period. Uniform values of nickel show lithogenic origin and low concentration in the present study, they are still rich enough to suggest an anthropogenic contribution. This is confirmed by comparison of the present data with the Adyar estuary [Achyuthan et al., 2002]. The lead concentration was found significantly $(\mathrm{p}<0.05)$ varied from 0.312 to $1.220 \mu \mathrm{g} / \mathrm{g}$. The maximum lead value of 1.220 $\mu \mathrm{g} / \mathrm{g}$ was observed in station 1 from monsoon season and the minimum value of $0.312 \mu \mathrm{g} / \mathrm{g}$ was observed in station 2 from post monsoon season whereas average range $(3.457 \mu \mathrm{g} / \mathrm{g})$ of lead was recorded from all other station throughout the study period. Attributed high $\mathrm{Pb}$ concentrations to several sources, such as boat exhaust systems, spillage of oil, and other petroleum from mechanized boats employed for fishing, and the discharge of sewage effluents into water, in which all of these sources exist in the studied areas [AbuHilal et al., 1987; Laxen et al., 1983] and the Zinc concentration was found significantly $(p<0.05)$ varied from 0.301 to $3.222 \mu \mathrm{g} / \mathrm{g}$. The maximum Zinc value of $3.222 \mu \mathrm{g} / \mathrm{g}$ was observed in station
1 from monsoon season and the minimum value of $0.301 \mu \mathrm{g} / \mathrm{g}$ was observed in station 4 from post monsoon season, whereas average range $(7.28033$ $\mu \mathrm{g} / \mathrm{g}$ ) of zinc was recorded from all other stations throughout the study period. Zinc always has a tendency to decomposition of the mangrove vegetative remains, which are found to release the accumulated heavy metals back to sediments. This process might be responsible for the strong association of zinc [Badarudeen et al., 1996].

The season variance correlation for the metals is shows good significant correlations. In premonsoon season heavy metals are highly correlation between $\mathrm{Fe}$ vs $\mathrm{Cr}(\mathrm{r}=0.983, \mathrm{P}<0.01), \mathrm{Mg}$ vs $\mathrm{Cr}(\mathrm{r}=0.962, \mathrm{P}<0.01), \mathrm{Mg}$ vs $\mathrm{Fe}(\mathrm{r}=0.934$, $\mathrm{P}<0.01)$, Ni vs $\mathrm{Cr}(\mathrm{r}=0.944, \mathrm{P}<0.01), \mathrm{Zn}$ vs $\mathrm{Cr}(\mathrm{r}$ $=0.919, \mathrm{P}<0.01), \mathrm{Zn}$ vs $\mathrm{Cu}(\mathrm{r}=0.942, \mathrm{P}<0.01)$, $\mathrm{Zn}$ vs $\mathrm{Ni}(\mathrm{r}=0.992, \mathrm{P}<0.01)$ and $\mathrm{Zn}$ vs $\mathrm{Pb}(\mathrm{r}=$ $0.9845, \mathrm{P}<0.01$ ), (Table.1). In monsoon season heavy metals are highly correlation between $\mathrm{Mn}$ vs $\mathrm{Fe}(\mathrm{r}=0.980, \mathrm{P}<0.01)$, Mn vs $\mathrm{Mg}(\mathrm{r}=0.929$, $\mathrm{P}<0.01)$, Silt vs $\mathrm{Zn}(\mathrm{r}=0.925, \mathrm{P}<0.01)$ (Table.2). In post monsoon season heavy metals are highly correlation between $\mathrm{Fe}$ vs $\mathrm{Cr}(\mathrm{r}=0.961, \mathrm{P}<0.01)$, Ni vs $\mathrm{Cr}(\mathrm{r}=0.931, \mathrm{P}<0.01)$, $\mathrm{Pd}$ vs $\mathrm{Cr}(\mathrm{r}=0.945$, $\mathrm{P}<0.01), \mathrm{Mn}$ vs $\mathrm{Cu}(\mathrm{r}=0.967, \mathrm{P}<0.01)$, $\mathrm{Ni}$ vs $\mathrm{Cu}$ $(\mathrm{r}=0.952, \mathrm{P}<0.01), \mathrm{Zn}$ vs cu $(\mathrm{r}=0.955, \mathrm{P}<0.01)$ (Table 3). In summer season heavy metals are highly correlation between $\mathrm{Fe}$ vs $\mathrm{Cr}(\mathrm{r}=0.969$, $\mathrm{P}<0.01), \mathrm{Mg}$ vs $\mathrm{Cu}(\mathrm{r}=0.967, \mathrm{P}<0.01) \mathrm{Mg}$ vs $\mathrm{Fe}$ $(\mathrm{r}=0.926, \mathrm{P}<0.01)$, Ni vs $\mathrm{Cu}(\mathrm{r}=0.945, \mathrm{P}<0.01)$ $\mathrm{Zn}$ vs $\mathrm{Cu}(\mathrm{r}=0.927, \mathrm{P}<0.01), \mathrm{Zn}$ vs $\mathrm{Ni}(\mathrm{r}=0.955$, $\mathrm{P}<0.01$ ) (Table 4). The good correlation of $\mathrm{Fe}$ versus $\mathrm{Cu}, \mathrm{Cr}, \mathrm{Ni}, \mathrm{Pb}$ and $\mathrm{Zn}$ indicates that these metals are contributed by the Fe oxides [Sipos, 2010; Sipos et al., 2011]. Incidentally, the mangrove stations with more silt and clay have higher

Table 1. Shows good significant correlations of heavy metals in pre-monsoon season

\begin{tabular}{|c|c|c|c|c|c|c|c|c|c|c|c|c|}
\hline & $\mathrm{Cd}$ & $\mathrm{Cr}$ & $\mathrm{Cu}$ & $\mathrm{Fe}$ & $\mathrm{Mg}$ & $\mathrm{Mn}$ & $\mathrm{Ni}$ & $\mathrm{Pb}$ & $\mathrm{Zn}$ & Clay & Silt & Sand \\
\hline $\mathrm{Cd}$ & 1 & & & & & & & & & & & \\
\hline $\mathrm{Cr}$ & -0.741 & 1 & & & & & & & & & & \\
\hline $\mathrm{Cu}$ & -0.437 & 0.737 & 1 & & & & & & & & & \\
\hline $\mathrm{Fe}$ & -0.712 & $0.983^{\star \star}$ & 0.659 & 1 & & & & & & & & \\
\hline $\mathrm{Mg}$ & $-0.823^{*}$ & $0.962^{* *}$ & 0.751 & $0.934^{\star \star}$ & 1 & & & & & & & \\
\hline $\mathrm{Mn}$ & -0.640 & 0.591 & 0.515 & 0.469 & 0.703 & 1 & & & & & & \\
\hline $\mathrm{Ni}$ & -0.603 & $0.944^{\star \star}$ & $0.904^{\star}$ & $0.893^{\star}$ & $0.898^{*}$ & 0.573 & 1 & & & & & \\
\hline $\mathrm{Pb}$ & -0.450 & $0.910^{*}$ & $0.845^{*}$ & $0.907^{*}$ & $0.843^{*}$ & 0.377 & 0.950 ** & 1 & & & & \\
\hline $\mathrm{Zn}$ & -0.595 & $0.919^{* *}$ & $0.942^{* *}$ & $0.866^{*}$ & $0.901^{*}$ & 0.583 & $0.992^{* *}$ & $0.945^{\star \star}$ & 1 & & & \\
\hline Clay & 0.455 & -0.352 & 0.091 & -0.324 & -0.441 & -0.729 & -0.143 & -0.064 & -0.118 & 1 & & \\
\hline Silt & -0.362 & 0.334 & 0.155 & 0.437 & 0.470 & 0.062 & 0.178 & 0.341 & 0.238 & -0.245 & 1 & \\
\hline Sand & -0.132 & 0.062 & -0.195 & -0.039 & 0.039 & 0.594 & -0.007 & -0.197 & -0.073 & -0.696 & -0.526 & 1 \\
\hline
\end{tabular}


Table 2. Shows good significant correlations of heavy metals in monsoon season

\begin{tabular}{|c|c|c|c|c|c|c|c|c|c|c|c|c|}
\hline & $\mathrm{Cd}$ & $\mathrm{Cr}$ & $\mathrm{Cu}$ & $\mathrm{Fe}$ & $\mathrm{Mg}$ & $\mathrm{Mn}$ & $\mathrm{Ni}$ & $\mathrm{Pb}$ & $\mathrm{Zn}$ & Clay & Silt & Sand \\
\hline $\mathrm{Cd}$ & 1 & & & & & & & & & & & \\
\hline $\mathrm{Cr}$ & -0.246 & 1 & & & & & & & & & & \\
\hline $\mathrm{Cu}$ & -0.192 & -0.109 & 1 & & & & & & & & & \\
\hline $\mathrm{Fe}$ & -0.495 & 0.811 & -0.499 & 1 & & & & & & & & \\
\hline $\mathrm{Mg}$ & -0.149 & 0.795 & -0.652 & $0.910^{\star}$ & 1 & & & & & & & \\
\hline $\mathrm{Mn}$ & -0.422 & $0.905^{*}$ & -0.409 & $0.980^{* *}$ & 0.929 ** & 1 & & & & & & \\
\hline $\mathrm{Ni}$ & -0.200 & $0.937^{* *}$ & -0.159 & 0.755 & 0.805 & $0.857^{*}$ & 1 & & & & & \\
\hline $\mathrm{Pb}$ & -0.510 & $0.899^{*}$ & 0.006 & 0.791 & 0.634 & $0.843^{*}$ & $0.867^{*}$ & 1 & & & & \\
\hline $\mathrm{Zn}$ & -0.474 & $0.853^{*}$ & 0.247 & 0.611 & 0.520 & 0.716 & $0.892^{*}$ & $0.909^{*}$ & 1 & & & \\
\hline Clay & 0.334 & -0.038 & 0.305 & -0.280 & -0.191 & -0.209 & -0.264 & -0.360 & -0.256 & 1 & & \\
\hline Silt & -0.689 & 0.719 & 0.427 & 0.537 & 0.300 & 0.602 & 0.683 & $0.882^{*}$ & $0.925^{\star *}$ & -0.229 & 1 & \\
\hline Sand & 0.045 & -0.349 & -0.527 & -0.016 & 0.025 & -0.121 & -0.110 & -0.123 & -0.248 & $-0.852^{\star}$ & -0.315 & 1 \\
\hline
\end{tabular}

Table 3. Shows good significant correlations of heavy metals in post-monsoon season

\begin{tabular}{|c|c|c|c|c|c|c|c|c|c|c|c|c|}
\hline & $\mathrm{Cd}$ & $\mathrm{Cr}$ & $\mathrm{Cu}$ & $\mathrm{Fe}$ & $\mathrm{Mg}$ & $\mathrm{Mn}$ & $\mathrm{Ni}$ & $\mathrm{Pb}$ & $\mathrm{Zn}$ & Clay & Silt & Sand \\
\hline $\mathrm{Cd}$ & 1 & & & & & & & & & & & \\
\hline $\mathrm{Cr}$ & 0.611 & 1 & & & & & & & & & & \\
\hline $\mathrm{Cu}$ & 0.547 & 0.800 & 1 & & & & & & & & & \\
\hline $\mathrm{Fe}$ & 0.625 & $0.961^{\star \star}$ & $0.890^{*}$ & 1 & & & & & & & & \\
\hline $\mathrm{Mg}$ & 0.480 & 0.686 & $0.915^{*}$ & 0.751 & 1 & & & & & & & \\
\hline $\mathrm{Mn}$ & 0.457 & $0.872^{*}$ & $0.967^{* *}$ & $0.947^{* *}$ & $0.867^{*}$ & 1 & & & & & & \\
\hline $\mathrm{Ni}$ & 0.612 & $0.937^{* *}$ & $0.952^{* *}$ & $0.970^{* *}$ & $0.880^{*}$ & $0.972^{* *}$ & 1 & & & & & \\
\hline $\mathrm{Pb}$ & 0.399 & $0.945^{\star *}$ & $0.870^{*}$ & $0.923^{* *}$ & 0.779 & $0.937^{* *}$ & $0.946^{* *}$ & 1 & & & & \\
\hline $\mathrm{Zn}$ & 0.444 & $0.834^{*}$ & $0.955^{\star *}$ & $0.874^{*}$ & $0.956^{\star *}$ & $0.960^{* *}$ & $0.959^{* *}$ & $0.925^{\star *}$ & 1 & & & \\
\hline Clay & 0.641 & 0.497 & 0.487 & 0.608 & 0.56 & 0.515 & 0.576 & 0.353 & 0.493 & 1 & & \\
\hline Silt & -0.730 & -0.198 & -0.446 & -0.286 & -0.61 & -0.286 & -0.395 & -0.109 & -0.397 & -0.684 & 1 & \\
\hline Sand & -0.391 & -0.531 & -0.365 & -0.623 & -0.36 & -0.500 & -0.514 & -0.398 & -0.403 & $-0.892^{*}$ & 0.281 & 1 \\
\hline
\end{tabular}

Table 4. Shows good significant Correlations of heavy metals in summer season

\begin{tabular}{|c|c|c|c|c|c|c|c|c|c|c|c|c|}
\hline & $\mathrm{Cd}$ & $\mathrm{Cr}$ & $\mathrm{Cu}$ & $\mathrm{Fe}$ & $\mathrm{Mg}$ & $\mathrm{Mn}$ & $\mathrm{Ni}$ & $\mathrm{Pb}$ & $\mathrm{Zn}$ & Clay & Silt & Sand \\
\hline $\mathrm{Cd}$ & 1 & & & & & & & & & & & \\
\hline $\mathrm{Cr}$ & -0.017 & 1 & & & & & & & & & & \\
\hline $\mathrm{Cu}$ & -0.265 & 0.768 & 1 & & & & & & & & & \\
\hline $\mathrm{Fe}$ & -0.145 & $0.969^{\star \star}$ & $0.833^{*}$ & 1 & & & & & & & & \\
\hline $\mathrm{Mg}$ & -0.247 & $0.818^{*}$ & $0.920^{* \star}$ & $0.926^{* *}$ & 1 & & & & & & & \\
\hline $\mathrm{Mn}$ & -0.183 & $0.914^{*}$ & $0.910^{*}$ & $0.889 *$ & $0.816^{*}$ & 1 & & & & & & \\
\hline $\mathrm{Ni}$ & -0.217 & $0.917^{*}$ & $0.945^{\star \star}$ & $0.941^{* *}$ & $0.916^{*}$ & $0.963^{* *}$ & 1 & & & & & \\
\hline $\mathrm{Pb}$ & 0.139 & $0.937^{\star *}$ & 0.619 & $0.863^{*}$ & 0.660 & 0.809 & $0.829^{*}$ & 1 & & & & \\
\hline $\mathrm{Zn}$ & -0.067 & $0.869 *$ & $0.927^{\text {** }}$ & $0.840^{*}$ & 0.801 & $0.977^{\star \star}$ & $0.955^{\star \star}$ & 0.799 & 1 & & & \\
\hline Clay & -0.118 & 0.334 & 0.449 & 0.335 & 0.359 & 0.473 & 0.319 & 0.028 & 0.395 & 1 & & \\
\hline Silt & 0.204 & -0.665 & -0.463 & -0.747 & -0.697 & -0.497 & -0.526 & -0.430 & -0.363 & -0.561 & 1 & \\
\hline Sand & -0.097 & 0.370 & 0.030 & 0.458 & 0.379 & 0.042 & 0.235 & 0.437 & -0.022 & -0.442 & -0.495 & 1 \\
\hline
\end{tabular}

concentrations of these metals [Nobi et al., 2010]. In the present studies the lagoon coastal ecosystem of the Muthupettai is still in its pristine stage. As there are not enough studies for this part of the study area for comparing the sediment quality, the information collected through the present study can be used as baseline data for future monitoring of the pristine nature of the lagoon. In general, the results inferred the contribution of meteorological factor, anthropogenic activity and the land use on 
the variation of heavy metals in urban soils. Nevertheless, a further detailed study is deemed necessary for appropriate and fine scale modeling.

\section{Spatial distribution}

The spatial distribution of heavy metals was found insignificant $(\mathrm{p}>0.05)$ variance in distribution of heavy metals concentration in sediments along the 6 different stations of Muthupet lagoon were shown in the Fiures 4A-D. The distribution reflects the presence of major pollution sources such as Muthupet Lagoon, sewage input from rivers, industrial and urban effluent input along the coast. The metal concentration in pre monsoon season was found in the order as follows $\mathrm{Fe}>\mathrm{Mg}>\mathrm{Mn}>\mathrm{Cr}>\mathrm{Zn}>\mathrm{Cu}>\mathrm{Ni}>\mathrm{Pb}>\mathrm{Cd}$.

Similarly the metal concentration range in monsoon, post monsoon and summer are in the order $\mathrm{Fe}>\mathrm{Mg}>\mathrm{Mn}>\mathrm{Zn}>\mathrm{Cu}>\mathrm{Cr}>\mathrm{Ni}>\mathrm{Pb}>\mathrm{Cd}, \mathrm{Fe}>\mathrm{Mg}$ $>\mathrm{Mn}>\mathrm{Cu}>\mathrm{Zn}>\mathrm{Pb}>\mathrm{Cr}>\mathrm{Ni}>\mathrm{Cd}$ and $\mathrm{Fe}>\mathrm{Mg}>\mathrm{Mn}>$ $\mathrm{Cr}>\mathrm{Zn}>\mathrm{Pb}>\mathrm{Ni}>\mathrm{Cu}>\mathrm{Cd}$ respectively. Heavy metal accumulations showed a decreasing trend from the northern part to southern part of the study area and also towards the sea from shore. The distribution reflects the presence of major pol- lution sources such as Chennai harbor, sewage input from Cooum and Adayar rivers, industrial and urban effluent input along the coast [Veerasingam et al., 2011]. Among all the metal Iron found to be maximum in all the station in all the season followed by magnesium and manganese. Apart from these three metal all other six metals are recorded in moderate range. The reasons for the high accumulations of these metals are anthropogenic activity, agriculture, aquaculture and the rivers regular in and out flow throughout the study duration in the lagoon area and also due to the stagnancy of water in the lagoon area. Furthur research is needed in the study area for checking the heavy metal concentration in the sediment of the lagoon area.

In the present study high values of $\mathrm{Fe}, \mathrm{Mg}$ and $\mathrm{Mn}$ in lagoon area could be ascribed to the high silt and clay contents that can adsorb metals by fine-grained particles. In Muthupettai lagoon hundreds of small and big vessels are used for fishing; this may be another reason for the higher concentration of heavy metals in the study area. The heavy metals in the study area are accumulated due to fishing actives. The present study compares the levels and distributions of eight
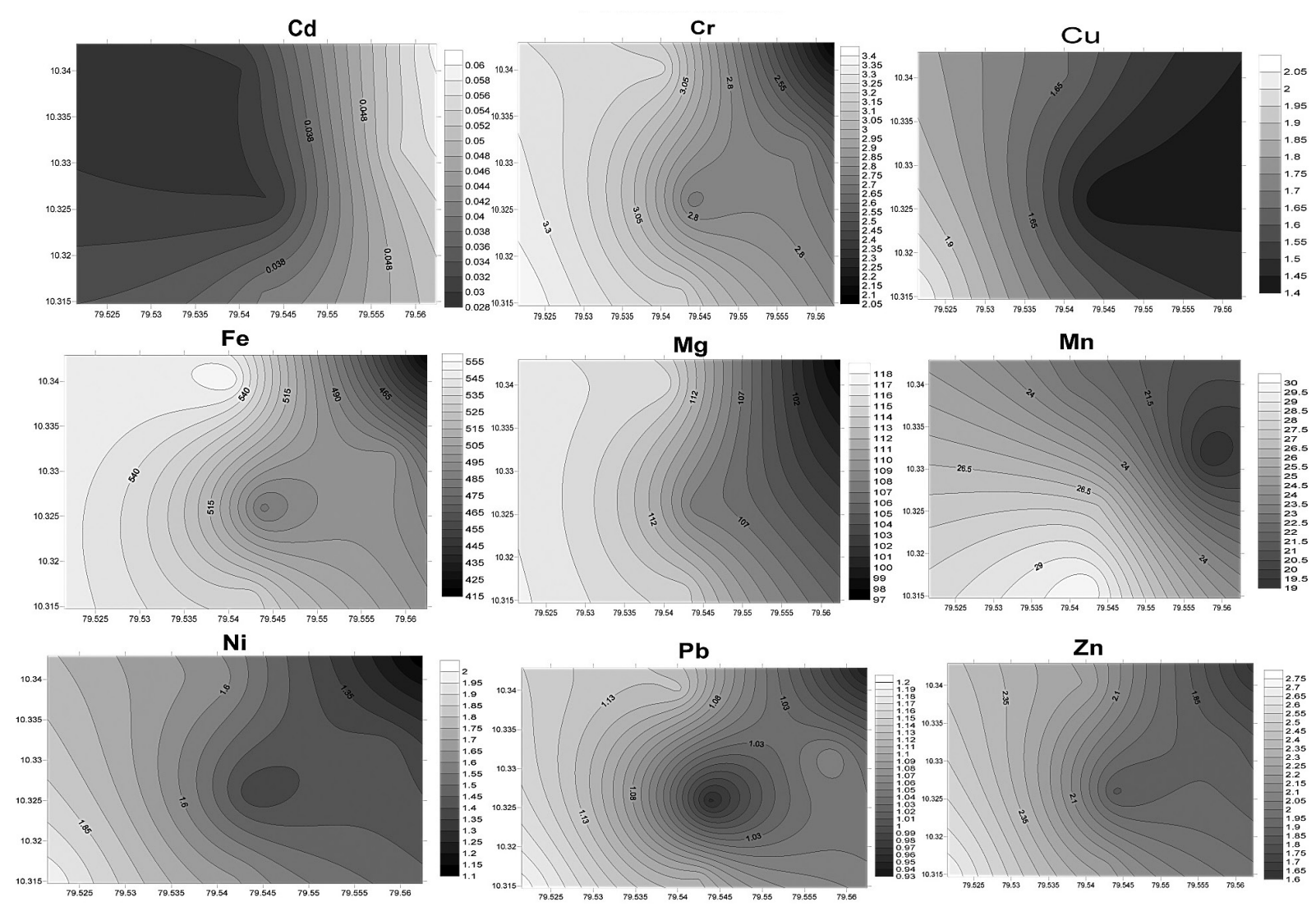

Figure 4A. Spatial distribution of heavy metals concentration in sediments of pre-monsoon season 

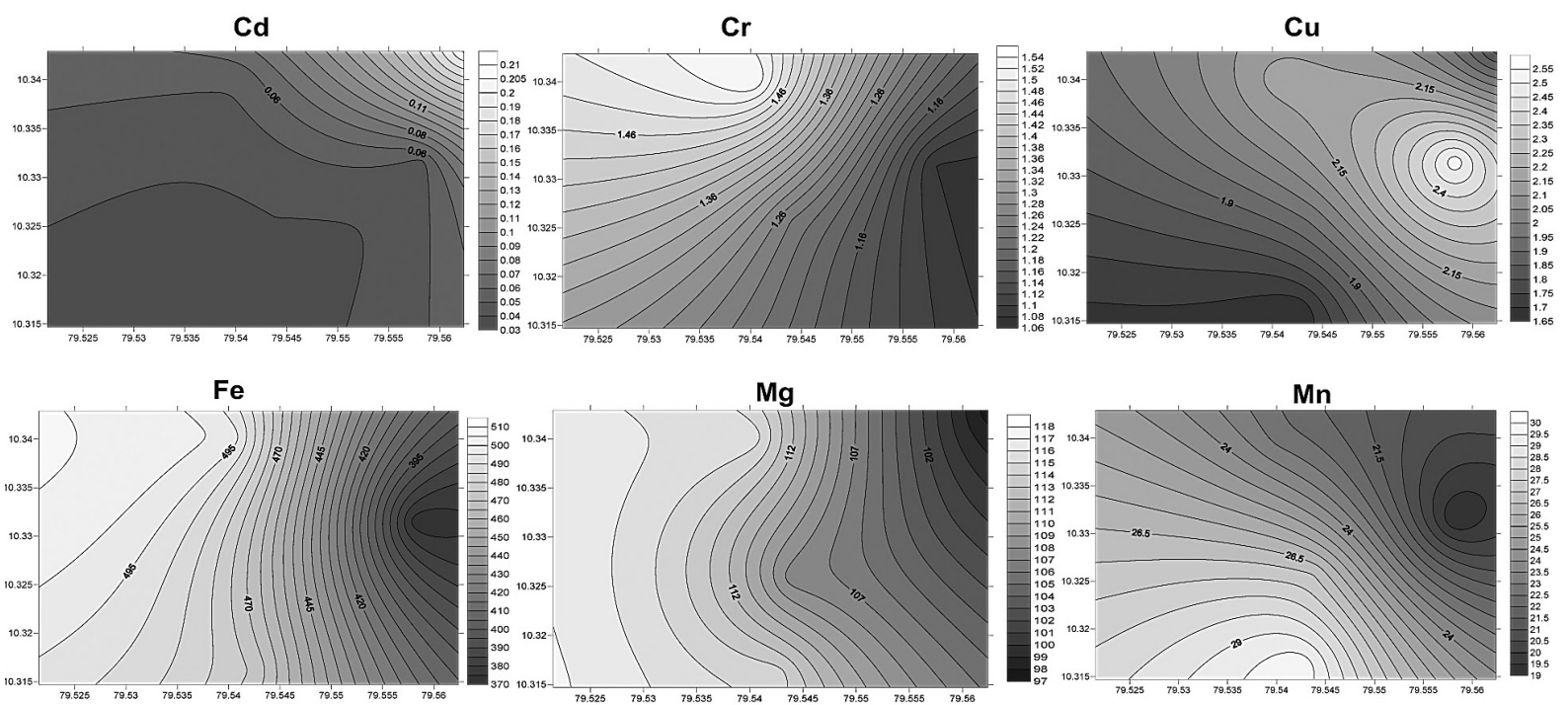

$\mathrm{Ni}$

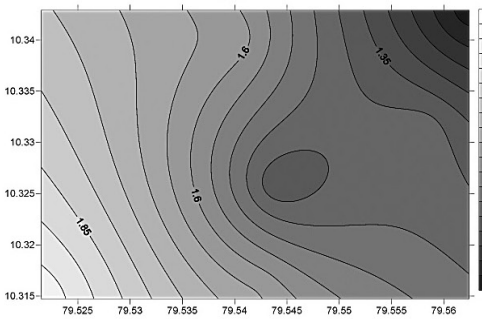

Figure 4B. Spatial distribution of heavy metals concentration in sediments of monsoon season
$\mathrm{Zn}$
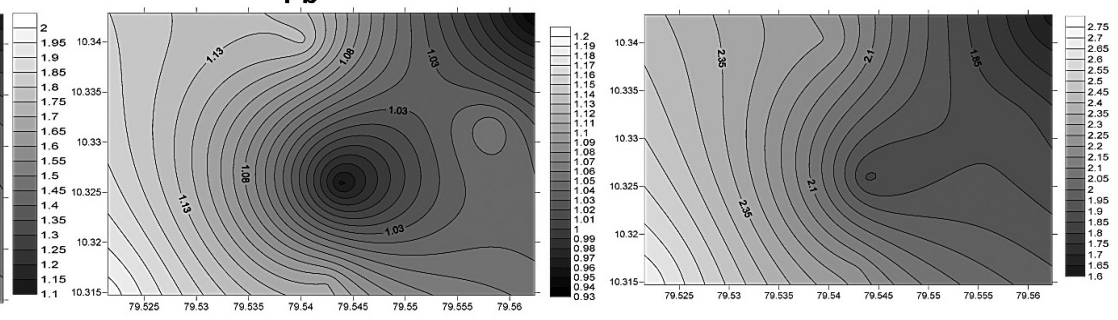

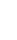

$$
\text { (1) }
$$




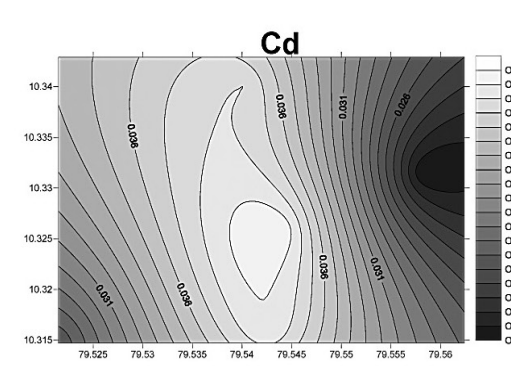

$\mathrm{Fe}$

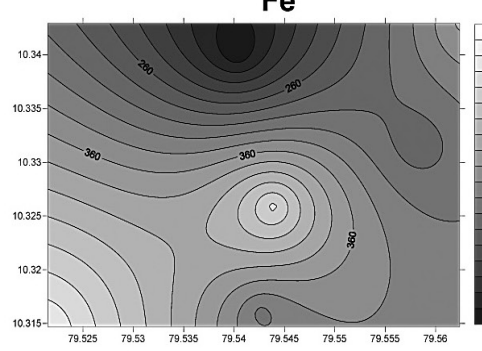

$\mathrm{Ni}$

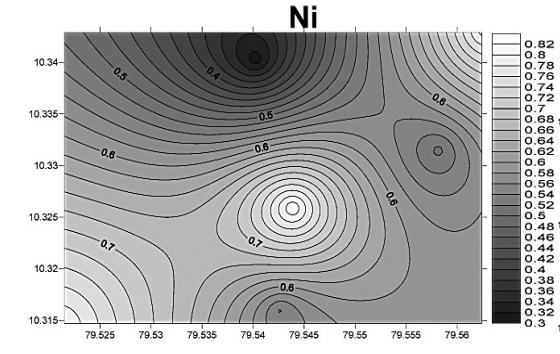

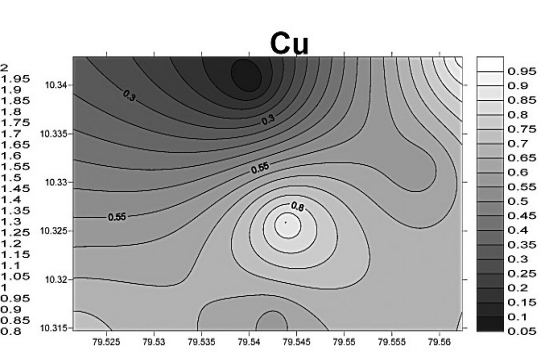

Mn

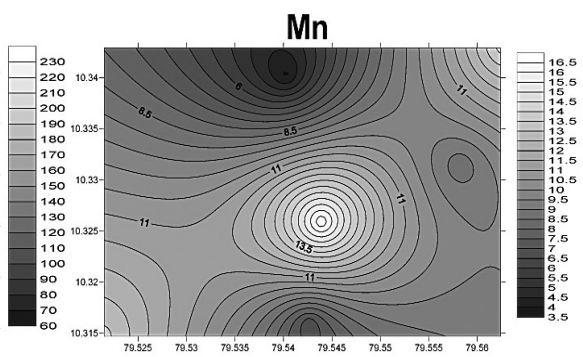

Zn

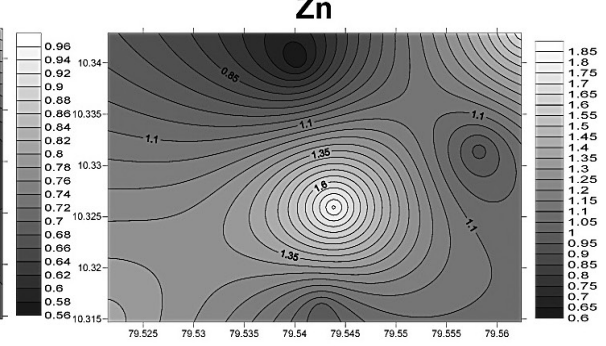

Figure 4D. Spatial distribution of heavy metals concentration in sediments of summer season

heavy metals in the sediments of four mangrove areas, namely Abu Dhabi, Umm al-Quwain, Ras al-Khaimah, and Khor Khuwair along the shoreline of the United Arab Emirates. In the present study area different types of mechanize and nonmechanized boats were used. While antifouling paints contain $\mathrm{Cu}$ and $\mathrm{Zn}$ at appreciable levels [Goldberg et al., 1976]. The concentrations of the metals $\left(\mu \mathrm{g} \mathrm{g}^{-1}\right)$ are as 28.8-169 for manganese, 4.59-22.4 for zinc, 3.12-6.94 for cadmium, 5.70-14.0 for cobalt, 8.28-18.9 for chromium, 5.31-29.4 for copper (mean 7.21), 14.8-109 for nickel, 13.2-49.8 for lead [Shriadah et al., 1999]. In Sabah mangrove sediment of Borneo Island, all the heavy metals have relatively higher concentration at high tide, compared to low tide; tides control the water-flows, carrying the sediments into the mangrove forest [Praveena et al., 2010]. This was mainly due to the discharges of aquaculture ponds, domestic wastes, and land agriculture drainages along with the rivers inputs into the sea near the study area. Apart from these sources, aquaculture and boating activities such as loading and unloading of materials, antifouling paints from boats and fishing activities contribute to the elevated levels of metals.

\section{Geo-accumulation index (Igeo)}

An approach to estimating the enrichment of metal concentration above background or baseline concentration is to calculate the geoaccumulation index (lgeo) as proposed by [Muller et al., 1969]. This is a quantitative measure of the metal pollution in aquatic sediments [Ranjan et al., 2008].

Calculated as follows:

$$
\mathrm{I}_{\text {geo }}=\operatorname{Iog}_{2}\left(\mathrm{C}_{\mathrm{n}} / 1.5 \mathrm{~B}_{\mathrm{n}}\right)
$$

where: $C_{n}-$ the concentration of the of the element in the samples,

$\mathrm{B}_{\mathrm{n}}$ - the geochemical background values or pristine values of the elements.

1.5 - the introduced to minimize the effect of possible variation in the background values.

The sediment environmental background values of permissible limits, according to WHO/ USEPA, in India are shown in Table 5. The heavy metal pollution is accumulated in sediment quality according to Igeo values listing as follows: Igeo $>5$ extremely contaminated, Igeo 4-5 strongly to extremely contaminated, Igeo 3-4 strongly 
Table 5. Heavy metal concentration $(\mu \mathrm{g} / \mathrm{g})$ of lagoon sediments in the study area and background values in India

\begin{tabular}{|c|c|c|c|c|}
\hline Metals & Maximum & Minimum & Mean & Background values \\
\hline $\mathrm{Fe}$ & 553.8 & 30.34 & 242.635 & 47200 \\
$\mathrm{Cr}$ & 3.398 & 0.159 & 1.15256 & 90 \\
$\mathrm{Mn}$ & 29.89 & 0.479 & 8.63304 & 850 \\
$\mathrm{Ni}$ & 1.994 & 0.084 & 0.62546 & 68 \\
$\mathrm{Cd}$ & 0.202 & 0.021 & 0.04129 & 0.3 \\
$\mathrm{~Pb}$ & 1.220 & 0.312 & 0.80277 & 20 \\
$\mathrm{Zn}$ & 3.222 & 0.301 & 1.52642 & 95 \\
$\mathrm{Cu}$ & 2.645 & 0.054 & 1.09906 & 58 \\
$\mathrm{Mg}$ & 225.2 & 12.79 & 80.6595 & - \\
\hline
\end{tabular}

Table 6. Potential ecological risk factor in the study, the minimum, maximum, mean were calculated

\begin{tabular}{|c|c|c|c|c|c|c|c|c|c|}
\hline Factor & $\begin{array}{c}\mathrm{Fe} \\
\text { Igeo }\end{array}$ & $\begin{array}{c}\mathrm{Cr} \\
\text { Igeo }\end{array}$ & $\begin{array}{c}\mathrm{Mn} \\
\text { Igeo }\end{array}$ & $\begin{array}{c}\mathrm{Ni} \\
\text { Igeo }\end{array}$ & $\begin{array}{c}\mathrm{Cd} \\
\text { Igeo }\end{array}$ & $\begin{array}{c}\mathrm{Pb} \\
\text { Igeo }\end{array}$ & $\begin{array}{c}\mathrm{Zn} \\
\text { Igeo }\end{array}$ & $\begin{array}{c}\mathrm{Cu} \\
\text { Igeo }\end{array}$ & $\begin{array}{c}\mathrm{Mg} \\
\text { Igeo }\end{array}$ \\
\hline Minimum & 11.18 & 9.72 & 11.36 & 10.25 & 4.42 & 6.59 & 8.88 & 10.65 & -- \\
Maximum & 6.99 & 5.31 & 5.40 & 5.67 & 1.15 & 4.61 & 5.46 & 5.03 & -- \\
Mean & 8.18 & 6.87 & 7.20 & 7.34 & 3.44 & 5.21 & 6.06 & 7.00 & -- \\
\hline
\end{tabular}

contaminated, Igeo2-3 moderately to strongly contaminated, 1-2 moderately contaminated, Igeo $0-1$ uncontaminated and $<0$ only uncontaminated. The result of the calculation of Geo-accumulation index (lgeo) in sediments is presented in Table 6 . The sediments are strongly to extremely contaminated by Fe (8.18), then flowed by Ni (7.34), $\mathrm{Mn}$ (7.20), $\mathrm{Cu}$ (7.00), Cr (6.87), Zn (6.06) and $\mathrm{Pb}$ (5.21), other heavy metals in moderately to strongly contaminated $\mathrm{Cd}$ (3.44), and the result of enrichment factor and lgeo has consistency the Muthupettai lagoon sediments was highly polluted through heavy metals.

\section{CONCLUSION}

The present study on concentration of heavy metals at ecosystems of Muthupet Lagoon confirmed that there are significant relationships between the seasons and the studies revealed insignificant relationships between the stations. The information obtained through the present study could be used as baseline data for future monitoring due to the lack of investigations to compare metal accumulation in this ecosystems in addition to compare with sediments back ground level and sediments quality guidelines using the statistical tools. Heavy metals were strongly present, yet continuous monitoring is necessary because the study area is vulnerable and also situated in a strategic location that the major fishing activities and main rivers have downstream and have direct opening to the coast and mangrove ecosystem.

\section{Acknowledgements}

We thank the authorities of Annamalai University and Dean and Director, Faculty of Marine sciences, Annamalai University, for providing necessary facilities during the course of our studies. We gratefully acknowledge the University Grant Commission for providing the financial support (UGC major project reference No. 40-152/2011(SR).

\section{REFERENCES}

1. Abu-Hilal A.H. 1987. Distribution of trace elements in near shore surface sediments from the Jordan Gulf of Agaba (Red Sea). Marine Pollution Bulletin, 18, 190-193.

2. Achyuthan H., Richardmohan D., Srinivasalu S., Selvaraj K. 2002. Trace metals concentrations in the sediment cores of estuary and tidal zones between Chennai and Pondicherry, along the east coast of India. Indian J. Mar. Sci. 31(2), 141-149.

3. Aitchison J. 1986. The statistical analysis of compositional data. Chapman and Hall London, Wiley New York, pp. 416.

4. Badarudeen A., Damodaran K.T., Sajan K., Pamela D. 1996. Texture and geochemistry of the sediments of a tropical mangrove ecosystem, southwest coast of India. Environmental Geology 27, 164-169.

5. Chinnaraja V.P., Santhanam B., Balaji P.S., Dinesh K., Jothiraj K. 2011. An investigation on heavy 
metals accumulation in water. Sediment and small marine food chain (plankton and fish) from Coromandel Coast, Southeast Coast of India. Indian J. of Natural Sci., 3(8).

6. Chork C.Y., Govett G.J.S. 1985. Comparison of interpretations of geochemical soil data by some multivariate statistical methods. Key Anacon, N.B., Canada. J. of Geochem. Explor., 23, 213-242.

7. Ergin M. Yörük R. 1990. Distribution and texture of bottom sediments in semi-enclosed coastal inlet, the Izmit Bay from the eastern Sea of Marmara (Turkey). Estuar Coast Shelf Sci. 30, 647-654.

8. Everaarts J.M. 1989. Heavy metals $(\mathrm{Cu}, \mathrm{Zn}, \mathrm{Cd}$, $\mathrm{Pb}$ ) in sediment of the Java Sea, estuarine and coastal areas of the East Java and some deep-sea areas. Neth. J. Sea Res. 34, 403-413.

9. Furukawa K., Wolanski E., Mueller H. 1997. Currents and sediments transport in mangrove forests. Estuarine, Coastal and Shelf Sci. 44, 301-310.

10. Goldberg P. L. 1976. Production and transport of organic matter in mangrove dominated Gulf shoreline of the United Arab Emirates. Indian J. of Marine Sci. 29, 224-229.

11. Haiyan W., Stuanes A. 2003. Heavy metal pollution in air-water-soil-plant system of Zhuzhou City, Hunan Province, China. Water, Air and Soil Pollution 147, 79-107.

12. Ingram R.L. 1970. Procedures in sedimentary petrology. Wiley, New York, USA, 58-96.

13. Greaney K.M. 2005. An assessment of heavy metal contamination in the marine sediments of las perlas archipelago, Gulf of Panama. School of Life Sciences Heriot-Watt University, Edinburgh.

14. Laxen D.P.H. 1983. The chemistry of metal pollution in water. In: R.M. Horrison (Ed.) Pollution causes, effects and control. The Royal Society of Chemistry, London, pp. 104.

15. Manju P., Nair., Akhil P.S., Sujatha C.H. 2014. Toxic metal distribution in the core sediment of Cochin Estuarine System (CES). Int. J. Environ. Res. 8(1), 133-138.

16. Marathe R.B., Maratha Y.V., Sawant C.P. 2011. Sediment characteristics of Tapti River, Maharashtra, India. Int. J. Chem. Tech. Res. 3(3), 1179-1183,

17. Mremi S.D., Machiwa J.F. 2003. Heavy metal contamination of mangrove sediments and the associated biota in Dar es Salaam, Tanzania. Tanzania Journal of Science, 29(1), 61-76.

18. Mtanga A., Machiwa J. 2007. Assessment of heavy metal pollution in sediment and polychaete worms from the Mzinga Creek and Ras Dege mangrove ecosystems, Dar es Salaam, Tanzania. Western Indian Ocean J. of Marine Sci., 6(2), 125-135.

19. Muller G. 1969. Index of geoaccumulation in sediments of the Rhine River. Geojournal 2(3), 108-118,

20. Nies D.H. 1999. Microbial heavy metal resistance. Applied Microbiol. and Biotechnol. 51, 730-750.
21. Nobi E.P., Dilipan E., Thangaradjou T., Sivakumar K., Kannan L. 2010. Geochemical and geo statistical assessment of heavy metal concentration in the sediments of different coastal ecosystems of Andaman Islands. India Estuarine Coastal and Shelf Sci., 87, 253-264.

22. Nolting R.F., Ramkema A., Everaarts J.M. 1999. The geochemistry of $\mathrm{Cu}, \mathrm{Cd}, \mathrm{Zn}, \mathrm{Ni}$ and $\mathrm{Pb}$ in sediment cores from the continental slope of the Banc deA Arguin (Mauritania). Cont. Shelf Res. 19, 665-691.

23. Praveena S.M., Ahmad A., Radojevic M. 2010. Heavy metals dyanamics and source in intertidal mangrove sediment of Sabah, Borneo Island. Environment Asia, 3 (spec. iss.), 79-83.

24. Ranjan R.K., Ramanathan A.L., Singh G., Chidambaram S. 2008. Assesment of metal enrichments in tsunamigenic sediments of Pichavaram mangrov es southeast coast of India. Environmental Monitoring and Assesment, DOI: 10.1007/s10661-007-0128.

25. Sankar R., Ramkumar L., Rajkumar M., Jun Sun, Ananthan G. 2010. Seasonal variations in physicochemical parameters and heavy metals in water and sediments of Uppanar estuary, Nagapattinam, India. J. of Environmental Biology 31(5), 681-686.

26. Shriadah M.M.A. 1999. Heavy metals in mangrove sediments of the United Arab Emirates Shoreline (Arabian Gulf). Water, Air and Soil Poll. 116, 523-534.

27. Sipos P. 2010. Sorption of copper and lead on soils and soil clay fractions with different clay mineralogy. Carpathian J. of Earth and Environ. Sci., 5, 111-118.

28. Sipos P., Nemeth T., May Z., Szalai Z. 2011. Accumulation of trace elements in Fe rich nodules in a neutral slightly alkaline floodplain soil. Carpathian J. of Earth and Environ. Sci., 6, 13-22.

29. Solai A.M., Suresh G., Kasilingam K., Sriraman E. 2013. Heavy metal accumulation in the surface sediments off pondicherry, bay of Bengal, South East Coast of India. Int. J. of Innovative Res. in Sci., Engin. and Technol., 2, 10.

30. Soto-Jiménez M.F., Páez-Osuna F. 2001. Distribution and normalization of heavy metal concentrations in mangrove and lagoonal sediments from Mazatlán Harbor (SE Gulf of California). Estuarine, Coastal and Shelf Sci. 53, 259-274.

31. Veerasingam S.; Venkatachalapathy R., Ramkumar T. 2011. Heavy metals and ecological risk assessment in Marine Sediments of Chennai, India. Carpathian J. of Eearth and Environ. Sci. 7(2), 111-124.

32. Thilagavathi B., Raja K., Bandana Das K., Saravanakumar A., Vijayalakshmi S., Balasubramanian T. 2011. Heavy metal distribution in sediments of Muthupettai Mangroves, South East Coast of India. J. Ocean Univ. China (Oceanic and Coastal Sea Research) 10 (4), 385-390.

33. Zainal A. 2000. Heavy metal pollution in sediments of coastal waters of Indonesia. Marine Poll. and Monit., 1-24. 